www.mrs.org/publications/bulletin

\title{
MRIS
}

YOUR G UIDE

TOMR S

MEM B ER

BENEFITS\&

SOCIETY

A C TIVITIES

2003 OFFICERS
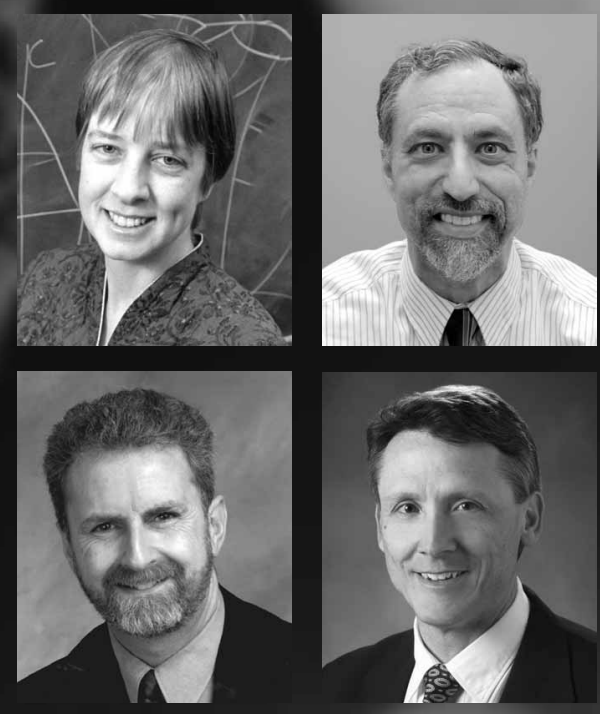

Merrilea J. Mayo, President

The National Academies

Howard E. Katz, Vice President*

Lucent Technologies

Alexander H. King, Immediate Past President Purdue University

Alan J. Hurd, Secretary

Los Alamos National Laboratories
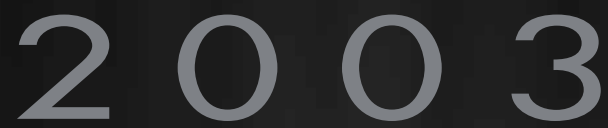

\section{BOARD OF DIRECTORS}

\section{Eduard Arzt}

Max Planck Institute for Metals Research

\section{Zhenan Bao*}

Lucent Technologies

Bruce M. Clemens

Stanford University

Tomás Díaz de la Rubia

Lawrence Livermore

National Laboratory
Jerry Floro

Sandia National

Laboratories

Ulrich Goesele*

Max Planck Institute of

Microstructure Physics

Peter F. Green

University of Texas-Austin

Mihal E. Gross

RAND Corporation
Linda L. Horton

Oak Ridge National Laboratory

Akihisa Inoue

Institute for Materials Research

Paul S. Peercy

University of Wisconsin

Yuri Suzuki*

University of CaliforniaBerkeley
Jerry Tersoff*

IBM T.J. Watson Research Center

Cynthia A. Volkert

Max Planck Institute for

Metals Research

Julia R. Weertman

Northwestern University

Executive Director

John B. Ballance

Materials Research Society 


\section{EXPAND YOUR KNOWLEDGE}

\section{MRS members for 2003 will enjoy increased access to the very latest materials information available.}

\author{
MRS BULLETIN \\ www.mrs.org/publications/bulletin/
}

As an MRS member, you can count on your FREE monthly subscription to MRS Bulletin (both in print and electronic format) for the best news and research overviews available today. The technical articles in the Bulletin are among the most highly cited in the field of materials research, consistently ranking in the top 10 among 170 materials science journals.

Theme topics for 2003 will include:

- Microelectronics Packaging

- Soft Error Rates in Microelectronic Circuits

- Superhard Coating Materials

- Cellular Solids

- Photonic Materials for Optical Communication

- Materials Science of Adhesives

- Advanced Fabrics

- Ultrahigh-Temperature Materials for Jet Engines

- Spin-Polarized Materials for Spintronics

- Inkjet Printing of Electronic and Structural Materials

- Application of Neutron Scattering to Materials Science

In addition, Washington News will expand its scope to become Science Policy, highlighting international policy news that affects the global materials research community.

\section{MRS SYMPOSIUM PROCEEDINGS www.mrs.org/publications/books/}

The MRS Symposium Proceedings Series, a long-standing standard reference in many areas of materials science, now includes over 6,600 proceedings papers available FREE online to members, with more added daily. This massive database provides a critical resource for researchers entering new fields, or following new developments in established fields. It is an ideal reference for graduate students, corporate scientists and engineers, and overseas researchers needing access to current information without the lag time of printing and mail delivery.

For our more archivally-minded members, print volumes of the MRS proceedings are available at $15-30 \%$ off list price. Check the 2003 Publications Catalog or the MRS Web site for the most current listings.

\section{JOURNAL OF MATERIALS RESEARCH www.mrs.org/publications/jmr/}

As an MRS member, you may subscribe to JMR, one of the foremost archival materials research journals in the world, at a very low member rate. And all print subscriptions to $J M R$ include exclusive FREE online Web access-full text of all $J M R$ articles from January 1996 to the current issue. New articles are posted electronically and are available for viewing approximately 4-6 weeks before the print issue arrives in the mail. For authors wishing to submit to $J M R$, we're pleased to announce that a new expedited review process has decreased the time to decision on a newly-submitted paper to below two months.

Your 2003 subscription also includes:

- Rapid Communications-brief reports of unusual urgency and significance to the materials research community. Upon their acceptance, preprints are immediately available through the Web to JMR subscribers.

- A comprehensive index-all articles contained in Volume 18 (January-December 2003) listed by topic and by author. This is published in the December 2003 issue.

\section{MIJ-NSR \\ nsr.mij.mrs.org/}

MRS Internet Journal of Nitride Semiconductor Research (MIJ-NSR) is a fully electronic, peer-reviewed archival journal, featuring technical papers on the leading edge of nitride semiconductor research. Registration is FREE to MRS members.

\section{E-MAIL ALERTS www.mrs.org/gateway/}

MRS members are invited to sign up for FREE member e-mail alerts aimed at providing new materials information quickly.

- Publications Alert delivers, in advance, tables of contents or JMR and MRS Bulletin. Subscribe at mrs-pubs-alertsubscribe@mrs.org

- MRS E-News delivers the latest research highlights and professional opportunities. Subscribe at mrs-enews-subscribe@mrs.org.

- MRS Public Affairs Alert provides occasional summaries of current public-policy issues affecting the materials science and engineering community. Learn how you can make a difference. Subscribe at mrs-publicaffairs-subscribe@mrs.org. 


\section{CONNECT WITH GREAT MINDS}

\section{MRS offers its members a broad and exciting array of networking opportunities.}

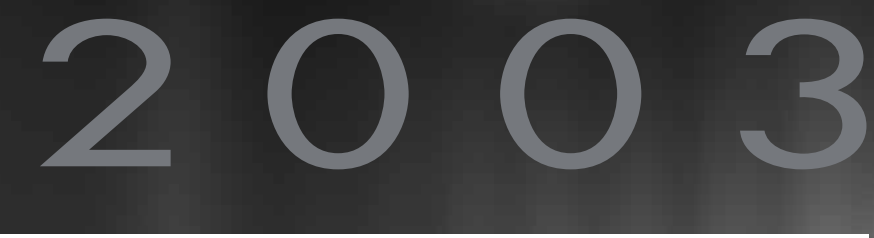

\section{MEMBERSHIP DIRECTORY www.mrs.org/membership/}

The MRS Online Membership Directory is a professional networking service available exclusively to our members. Updated regularly, it is a quick and easy way for you to search for colleagues by name, institution or geographical location.

\section{CAREER OPPORTUNITIES www.mrs.org/career_services/}

Opportunities for you to expand your career or your company include the MRS Spring and Fall Meeting Career Centers, the most efficient forums available for pursuing employment or filling materials research positions. In addition, MRS Bulletin advertises a wide range of materials-related professional openings in industry, academia, government and research worldwide. Listings are also posted on the MRS Web site each month for convenient online access.

\section{UNIVERSITY CHAPTERS \& SECTIONS www.mrs.org/university/ www.mrs.org/sections/}

University Chapters facilitate discussion between students and faculty and promote student interest in materials science. As a student member in 2003, you may network among 32 active Chapters in the U.S., compare notes on recent activities and brainstorm with other students on new projects and issues of common concern. MRS Sections provide convenient regional forums for the interaction of scientists and engineers in various materials disciplines of particular interest to that community.

\section{INTERNATIONAL COLLABORATIONS www.mrs.org/gateway/iumrs.html}

MRS works closely with other materials organizations around the word and is an Adhering Body of IUMRS (International Union of Materials Research Societies). This collaboration facilitates international cooperation among materials research organizations and helps to advance the multidisciplinary nature of the materials research community. Link directly to IUMRS at www.iumrs.org for general information, a list of officers, publications, and upcoming meeting information. 


\section{GAIN RECOGNITION}

\section{You may recognize your colleagues, or be recognized yourself, for outstanding research contributions.}

\author{
MRS AWARDS \\ www.mrs.org/awards/
}

The MRS Awards Program acknowledges outstanding contributions to the progress of materials research, honoring those whose work has already impacted the field, as well as those whose work shows great promise for future leadership.

The Von Hippel Award, the Materials Research Society's highest honor, recognizes those qualities most prized by materials scientists and engineers-brilliance and originality of intellect, combined with vision that transcends the boundaries of conventional scientific disciplines. The deadline for receipt of new nominations is June 1 of each year.

The David Turnbull Lectureship recognizes the career of a scientist who has made outstanding contributions to understanding materials phenomena and properties through research, writing, and lecturing, as exemplified by the life work of David Turnbull. The recipient will present a technical lecture of broad appeal at the MRS Fall Meeting, and may be asked to speak at MRS Section and University Chapter meetings. Nominations are due June 1 of each year.

The MRS Medal recognizes an exceptional recent achievement in materials research which is expected to have a major impact on the progress of any materials-related field. Nominations are due June 1 of each year.

The MRS Outstanding Young Investigator Award recognizes outstanding, interdisciplinary scientific work in materials research by a young scientist or engineer. The award recipient must also show exceptional promise as a developing leader in the materials area. The deadline for receipt of new nominations is October 1 of each year.

MRS Graduate Student Awards honor and encourage graduate students whose academic achievements and current materials research display a high order of excellence and distinction. Finalists compete for Gold and Silver Medals at the MRS Spring and Fall Meetings. Applications are due approximately 5 months preceding each MRS meeting.

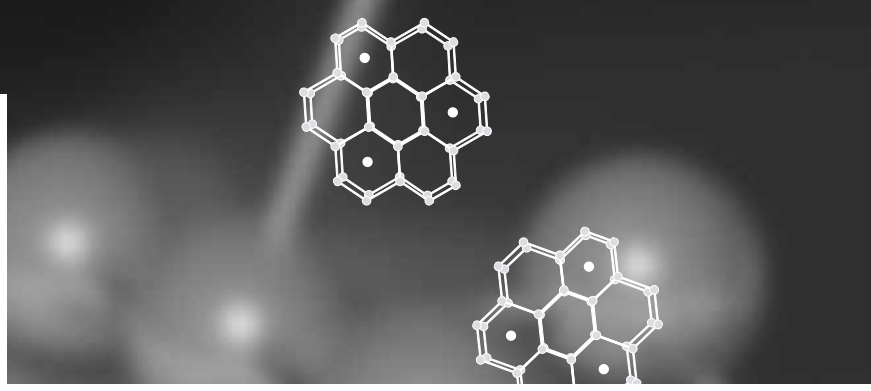

\section{PUBLISHING OPPORTUNITIES www.mrs.org/publications/}

Publishing venues for MRS members include the MRS Bulletin and Journal of Materials Research. To propose a theme topic for MRS Bulletin, or for information on guest-editor opportunities, contact the Bulletin editor. For authors wishing to submit to $J M R$, we are pleased to announce that the Journal's new expedited review process has decreased the time to decision on a newly-submitted paper to below two months.

In addition, the MRS Symposium and Conference Proceedings Series offer opportunities to publish papers presented at MRS meetings and other scientific and technical meetings.

\section{THE MRS/OSA CONGRESSIONAL FELLOWSHIP www.mrs.org/pa/fellowship/}

MRS, in conjunction with the Optical Society of America (OSA), is the proud sponsor of the MRS/OSA Congressional Science and Engineering Fellowship Program. This provides MRS/OSA members with an invaluable public-policy learning experience, while educating policy makers about the value of materials science.

The Fellow spends one year (beginning each September) working as a special legislative assistant on the staff of a member of Congress or Congressional Committee. Activities may involve conducting legislative work, assisting in Congressional hearings and debates, preparing briefs and writing speeches. The Fellow also attends an orientation program on Congressional and Executive Branch operations in addition to a year-long seminar series on science and public-policy issues.

Applications are currently being sought for the 2003-2004 Congressional Fellowship. The deadline for 2003 is January 15. 


\section{BECOME A VITAL PART}

MRS encourages you to become
active within the Society as well
as the larger community.

\section{SOCIETY MEMBER VOLUNTEERS www.mrs.org/geninfo/}

The tremendous growth and success of our Society is the result of member input and the energetic efforts of many MRS member volunteers. The MRS committee structure and task forces offer members an invaluable opportunity to participate in, and influence profoundly, the operation of the Society.

A recent radical restructuring of our governance has now made such volunteer activities even more effective than they have been in the past. If you have an interest in working on any aspect of MRS activity, contact Merrilea Mayo, 2003 MRS President at mmayo@nas.edu.

\section{SPECIAL INTEREST DISCUSSION GROUP-WOMEN IN MS\&E www.mrs.org/women/}

Women in Materials Science and Engineering is the subject of a special breakfast at both the MRS Spring and Fall Meetings and features a timely discussion about issues facing women in the materials research and engineering professions. Additionally, MRS members are encouraged to join the "Women in MS\&E" mailing list for a continuing discussion and exchange of ideas. Both women and men are welcome to participate. Subscribe at mrs-women-subscribe@mrs.org

\section{HIGH SCHOOL STUDENT WORKSHOPS www.mrs.org/pa/publicoutreach/}

The MRS Public Outreach Subcommittee sponsors a half-day Student Workshop in conjunction with the MRS Spring and Fall Meetings on materials topics relevant to middle- and highschool-age students. This hands-on workshop introduces the concept of materials and instills the excitement of scientific discovery. Recent workshops have delved into the subjects of polymers, data storage, and materials for sports. For more information, contact Bill Hammetter, Public Outreach Subcommittee Chair, at whamme@sandia.gov.

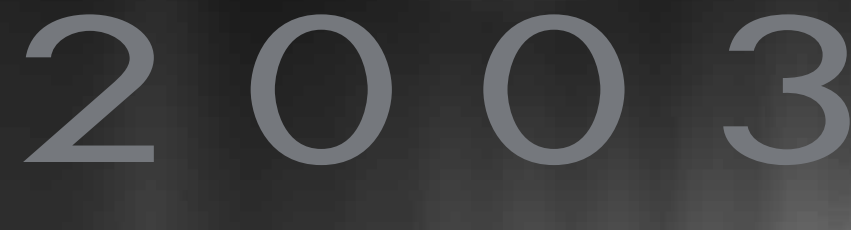

\section{MATERIALS MICROWORLD www.mrs.org/microworld/}

Materials MicroWorld is a hands-on, interactive travelling museum exhibition, targeting 5 th-8th graders, that will immerse visitors in the world of materials science. Opening in Toronto in June, 2003, Materials MicroWorld will have an associated, discovery-based Web page and curriculum content connections for teachers that focus on the hidden and active science of materials that shape our physical world-from the mundane to the mysterious.

Museums and science centers across the country will host the exhibition beginning in February, 2004. MRS members will have opportunities to contribute in each of the museum's local communities. For more information, contact Beth Stadler (University of Minnesota) at stadler@ece.umn.edu or Richard Souza (Materials Research Society) at souza@mrs.org.

This exhibition and its national tour are made possible by the National Science Foundation, Alcan, Dow, Ford Motor Company and $3 \mathrm{M}$.

\section{CORPORATE AFFILIATION www.mrs.org/mo/corporate/}

MRS Corporate Affiliates provide a vital link in the Society's promotion of close interaction among scientists and engineering professionals in the materials research community. Through networking and information exchange, your organization will be better able to develop products and services that are tailored to the needs of the research community-which in turn will generate additional partnership opportunities.

If your organization is interested in influencing the growth and direction of interdisciplinary, basic research on advanced materials, contact Mary E. Kaufold (Materials Research Society) at kaufold@mrs.org. 


\section{INVITE YOUR COLLEAUES}

To join, mail or fax this application to:

Materials Research Society

506 Keystone Drive

Warrendale, PA 15086 USA

Tel: 724-779-3003

Fax: $724-779-8313$

or join online at

www.mrs.org/membership/

\section{MRS \\ MEMBER BENEFITS}

\section{MRS Publications \& Online Resources}

- FREE print subscription to MRS Bulletin with

FREE electronic access as well

- Discounted rate to Journal of Materials Research which includes FREE Web access

- Opportunities to purchase MRS symposium proceedings at member discounts and enjoy FREE Web access to over 6,600 proceedings papers online

- FREE registration to MRS Internet Journal of Nitride Semiconductor Research

- Access to FREE MRS E-Mail Alerts

\section{MRS Networking Opportunities}

- Discounted registration fees for MRS meetings and workshops

- The online MRS Membership Directory

- Career development opportunities at MRS meetings and through the MRS Bulletin

- Student involvement in MRS University Chapters

- Regional forums for interaction through MRS Sections

- Access to information on international collaborations such as IUMRS

\section{Opportunities for Recognition}

- The MRS Awards Program

- Publishing venues including the monthly MRS Bulletin, Journal of Materials Research and MRS symposium proceedings

- The MRS/OSA Congressional Science and Engineering Fellowship Program

\section{Opportunities to Contribute}

- MRS volunteer opportunities

- Public outreach and education opportunities including Materials MicroWorld, "Women in Materials Science and Engineering," and high school student workshop involvement.

- Corporate Affiliation

\section{MEMBERSHIP APPLICATION}

$\square$ I am a new member $\square$ Please renew my membership

\section{MRS MEMBERSHIP RATES}

Rates are for 12 months and include complimentary subscription to MRS Bulletin and FREE access to online MRS proceedings.

A. Start membership (check one): $\square$ January 1, $2003 \quad \square$ July 1, 2003

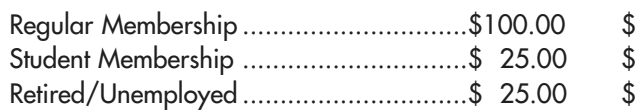

B. Include a Member Subscription to Journal of Materials Research with FREE online access.

U.S. Member Rate

$\$ 115.00$

Non-U.S. Member Rate (surface) ............\$155.00

Non-U.S. Member Rate (air freight) ........\$215.00

$\$$

$\$$

$\$$

C. Voluntary Contribution to support MRS student programs

(Tax deductible to contributor under U.S. tax laws.) 10.00

D. Total $(A+B+C)$

$\$$

$\$$

Allow 6-8 weeks for delivery of any back issues of subscriptions. Dues allocated to MRS Bulletin Subscription: \$29 Regular, \$17 Student

\section{PAYMENT INFORMATION}

$\square$ Check/money order enclosed — payable to Materials Research Society

$\square$ Bill my credit card: $\square$ MasterCard $\quad \square$ VISA $\square$ Diners Club $\square$ American Express

\section{Card No.}

Signature

\section{Exp. Date}

\section{BILLING \& SHIPPING ADDRESS}

Name: First Middle I. Last

Membership ID\# (if renewing)

Institution Dept./Mail Stop

\begin{tabular}{ll}
\hline P.O. Box Street &
\end{tabular}

Postal Code City

\begin{tabular}{lll}
\hline State/Province & Zip & Country
\end{tabular}

Tel: Country Area/City Local Number $\quad$ Fax: Country Area/City Local Number

E-mail address WWW address

NOTE: The address above will also be used in future MRS Membership Directories unless you provide an alternate.

\section{STUDENT APPLICANTS}

I am currently enrolled as a full-time student, or I am working full-time on a thesis or dissertation. 